\title{
Physical control of arctic ice algal production
}

\author{
Glenn F. Cota* , Edward P. W. Horne \\ Department of Fisheries and Oceans, Biological Sciences Branch, Bedford Institute of Oceanography, Dartmouth, Nova Scotia, \\ Canada B2Y 4A2
}

\begin{abstract}
Algal colonization of annual sea ice in the high Arctic approximates plate culture, presenting a model system for physiological studies of natural populations of marine microalgae. Time series of observations were made in the Northwest Passage during the latter half of the spring bloom. Although in situ temperature, salinity and irradiance were nearly constant, the photosynthetic performance of ice algae as indicated by maximum assimilation rates $\left(P_{m}{ }^{B}, \mathrm{mg} \mathrm{C} \mathrm{mg} \mathrm{chl}^{-1} \mathrm{~h}^{-1}\right)$ and photo-

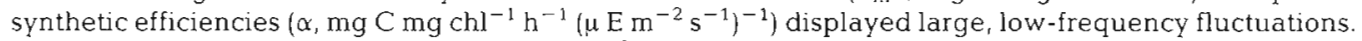
In contrast, the photoadaptive index, $I_{k}\left(\mu \mathrm{E} \mathrm{m}^{-2} \mathrm{~s}^{-1}\right)$, varied little up until the last few days of our study when snow cover melted and transmitted light increased rapidly. When compared to cells from other snow covers or light histories, algal populations from a snow-free area exhibited higher assimilation rates and photoadaptive indices but had similar photosynthetic efficiencies and lower standing stocks. Nutrient fluxes in the 'surface mixed layer' also varied by about an order of magnitude over the fortnightly tidal cycle. Tidally dominated vertical mixing results in a pulsed nutrient regime which is apparently reflected in a modulation of algal photosynthesis and growth.
\end{abstract}

\section{INTRODUCTION}

Under conditions of low light (ca 2 to $25 \mu \mathrm{E} \mathrm{m} \mathrm{m}^{-2} \mathrm{~s}^{-1}$ ) and temperature $\left(-1.8^{\circ} \mathrm{C}\right)$ in the high Canadian Arctic ice algae, predominantly pennate diatoms, form dense

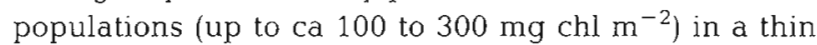
layer $(\mathrm{ca} 1 \mathrm{~cm}$ ) on the bottom of 1 to $2 \mathrm{~m}$ of annual sea ice (Apollonio 1961, 1965, Cota 1985, Cota et al. 1987, Smith et al. 1987, 1988). In addition to augmenting total marine productivity, ice algae extend the brief summer open water season of phytoplankton production by about 2 mo in spring. Seasonal fluctuations of sea ice cover are ca $7 \times 10^{6} \mathrm{~km}^{2}$ in the Arctic (Walsh \& Johnson 1979), and on annual sea ice, algal abundance normally

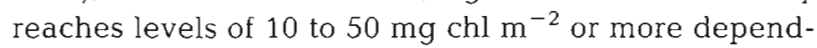
ing upon snow and ice conditions (Horner \& Schrader 1982, Horner 1985, Smith et al. 1988). These ice algae form one of the most intense chlorophyll maxima in any marine environment and presumably represent the most concentrated food resource that grazers ever encounter in this ecosystem (Bradstreet \& Cross 1982, Horner \& Schrader 1982, Carey 1985, Grainger et al. 1985, Conover et al. 1986).

The temporal development of algal populations in

\footnotetext{
- Present address: Graduate Program in Ecology, University
} of Tennessee, Knoxville, Tennessee 37996-1610, USA bottom ice can be followed with comparative ease, because they are fixed spatially in a relatively predictable and nearly planar environment and can be revisited repeatedly to document changes in biomass and physiology (Cota et al. 1987. Smith et al. 1987, 1988). There is little doubt that light availability has a major influence on ice algal biomass and production in the Arctic, Subarctic and Antarctic (Apollonio 1961, 1965, Clasby et al. 1976, Horner \& Schrader 1982, Gosselin et al. 1985, 1986, Horner 1985, Cota et al. 1987, Grossi et al. 1987, Smith et al. 1987, 1988, SooHoo et al. 1987), especially during the winter-spring transition when incident irradiance increases dramatically. Growth irradiance (in situ light level) can also be manipulated and maintained fairly easily by stabilizing surface snow cover with a low profile snow fence (Cota 1985). Therefore, ice algal communities may be studied in relatively constant light regimes for periods of weeks under stabilized snow cover (e.g. Smith et al. 1988) with much more 'control' and confidence. In contrast phytoplankton populations may experience large variations in irradiance over much shorter time scales due to vertical mixing, and must be considered in 3 dimensions with turbulent dispersion over time (e.g. Lewis et al. 1984).

Turbulent mixing has long been known to influence the growth or production of phytoplankton (Grann \& Braarud 1935, Sverdrup 1953, Lewis et al. 1984), while 
the potential impact of vertical mixing on populations of sea ice algae has only been considered very recently (Gosselin et al. 1985, Cota et al. 1987). The interplay between the environmental factors of light and nutrients are markedly different in planktonic (pelagic) versus sea ice (epontic) ecosystems. Ice algae are fixed in the vertical light gradient by virtue of their attachment to a buoyant substrate, the ice sheet. Consequently, only one major environmental variable, nutrient supply, is potentially altered by vertical mixing of the water under the ice. Variations in tidally induced mixing and nutrient flux appear to influence, if not control, ice algal nutrient status and physiological performance

Several independent lines of evidence have led to recent suggestions that inorganic nutrients may limit ice algal production (Grainger 1977, Gosselin et al. 1985, McConville et al. 1985, Palmisano \& Sullivan 1985, Maestrini et al. 1986, Cota et al. 1987, Smith et al. 1987). The role of tidally induced vertical mixing in the supply of nutrients to the ice algae in the Arctic has been considered in detail previously (Cota et al. 1987) and can be illustrated with simple biological and physical models. Biological demand for nutrient(s) must be less than or equal to physical supply when 'new' production predominates (Dugdale \& Goering 1967, Eppley \& Peterson 1979). This can be summarized by the relationship:

$$
\mu \cdot B_{n} \leq(\Delta n / \Delta z) \cdot K_{z}
$$

where $\mu=$ average algal growth rate $\left(\mathrm{d}^{-1}\right)_{i} B_{n}=$ algal biomass in terms of a given nutrient element (e.g. nitrogen or silicon in $\left.\mathrm{mmol} \mathrm{m}^{-2}\right) ; \Delta n / \Delta z=$ the vertical gradient $\left(\mathrm{mmol} \mathrm{m}^{-4}\right)$ for the nutrient of interest; $K_{z}=$ vertical eddy diffusivity $\left(\mathrm{m}^{2} \mathrm{~d}^{-1}\right)$. Biological demand and physical supply are represented, respectively, by the left and right sides of the equation above. Other sources of nutrient supply, including desalination of the ice sheet and nutrient regeneration, appear to satisfy only a portion of total algal demand, especially for silicon, integrated over entire blooms (Cota et al. 1987 and unpubl.).

The purpose of this investigation was to measure the photosynthetic responses of ice algae from natural populations in relation to major environmental variables. Specifically, we wished to determine if there was systematic variability in photosynthetic parameters between light environments (snow depths) and over time. We hypothesized that ice algae display photoadaptative states which are characteristic of their different light regimes (Cota 1985) and that a time series of photosynthetic responses in a population with the same light history would be diagnostic of potential nutrient stress when their nutrient supply may be pulsed at low frequency (Gosselin et al. 1985, Cota et al. 1987). Most of this study was conducted during May, a period when the physical environment is relatively constant compared to either April when incident irradiance increases markedly and the bloom progresses from very low biomass to near maximal levels or June when biomass usually declines very rapidly in response to the spring melt. We also hoped to test our nutrient demand-supply model against a more extensive data set with better temporal resolution.

\section{METHODS}

Our study area (ca $74^{\circ} 38^{\prime} \mathrm{N}, 94^{\circ} 53.5^{\prime} \mathrm{W}$ ) was near the center of the Northwest Passage through the Canadian Arctic Archipelago and has been described in detail elsewhere (Cota et al. 1987). The site was ca $4 \mathrm{~km}$ offshore ( $96 \mathrm{~m}$ depth) on land-fast, annual sea ice which was ca $1.85 \mathrm{~m}$ thick. The time series of ice algal observations presented here was confined to an area with low ( 3 to $5 \mathrm{~cm}$ ) snow cover. Discrete comparisons, corresponding in time to spring and neap tidal states, were also made on algal populations from a series of 4 snow depths representing different growth irradiances. The 4 populations were from a clear region $(0 \mathrm{~cm})$ or low $(3$ to $5 \mathrm{~cm})$, moderate $(10$ to $13 \mathrm{~cm})$ and heavy $(19$ to $23 \mathrm{~cm})$ snow covers. These algae were obtained from a stablized snow drift system and all populations had gone through several generations in their respective light environments. Most of our observations were made during an intensive period of sampling in May which corresponds roughly to the latter half of the algal bloom in 1985.

Collections of ice algae were made either with a SIPRE corer ( $7.6 \mathrm{~cm}$ diameter) before Julian Day 132 or after that time by subcoring $(2 \mathrm{~cm}$ diameter) larger chunks of bottom ice with an intact skeletal layer. These chunks were obtained by chipping out the last few centimeters of ice with an ice chisel in an augered hole $(22.9 \mathrm{~cm}$ diameter) and several subcores were combined in each case. Sampling frequency was increased from weekly collections in early season to daily or bidaily during the intensive physiological studies during the latter portion of the bloom. Chlorophyll biomass has been corrected for differences in the dilution volumes of core melts and expressed as an areal concentration according to:

$$
\begin{aligned}
& \text { mg chl m}{ }^{-2}= \\
& \text { (cores } \left.\left.\mathrm{m}^{-2}\right) \text { (volume core }{ }^{-1}\right) \cdot\left(\mathrm{mg} \mathrm{chl} \mathrm{m}^{-3}\right)
\end{aligned}
$$

where core melt volume has units of $\mathrm{m}^{3}$. To ensure that the surface area of bottom ice was comparable between the 2 sampling techniques, estimates of biomass for the later part of the study are presented as 2-day averages. Means of triplicate SIPRE cores had an average coefficient of variation of $13.9 \%$; replicate 
subcores were pooled for a single sample on each date and the variance of this sampling procedure was not evaluated.

All experimental suspensions were prepared by scraping the soft and loosely consolidated ice crystals from the bottom (skeletal layer) of ice cores directly into seawater. Final dilutions were around 10:1, seawater to melted ice, and had salinities (ppt) of 29 to 30 compared to about 32 for undiluted surface seawater. Methodological details for determinations of photosynthesis versus irradiance ( $P-I ; 24$ light levels) responses of the ice algae (Lewis \& Smith 1983, Cota 1985, Bates \& Cota 1986, Smith et al. 1987, 1988) and procedures for data analyses (Platt et al. 1980, Gallegos \& Platt 1981) have been reported previously. $P-I$ experiments were routinely conducted with a tungsten-halogen source transmitted through a seawater cooling cuvette (ca $5 \mathrm{~cm}$ ) and a blue acrylic ( $3 \mathrm{~mm}$ ) filter to simulate subice irradiance more closely. Photosynthetic measurements were conducted about solar noon ( $\pm 2 \mathrm{~h}$ ) to minimize possible diel periodicity. Algal biomass as chlorophyll a was estimated fluorometrically (Holm-Hansen et al. 1965) and all photosynthetic rates were normalized to biomass (denoted by superscript $B$ ). Irradiance levels were measured with a LICOR model LI192S cosine collector at the top of the aluminum photosynthetron block without a glass vial, seawater or algae. Reflection and attentuation in this system have been accounted for by a correction factor of 2.8. This factor was determined with a fiber optics adapter $(2 \pi$ collector, Bates \& Cota 1986, M. R. Lewis unpubl.) in vials with seawater and should be applied to irradiance data reported in Cota (1985).

Profiles of dissolved inorganic nutrients (nitrate, $\mathrm{NO}_{3}$ and silicic acid, $\left.\mathrm{Si}(\mathrm{OH})_{4}\right)$ in the water column were obtained daily at 16 depths $(0,1,2,3,5,7,9,12,15,20$, $25,30,40,50,70$ and $90 \mathrm{~m}$ ) during the last $3 \mathrm{wk}$ of the study. Water column structure and currents were studied with a Guildline Model 8770 CTD and a specially designed gyroscopic unmanned profiling system (GUMPS) (Cota et al. 1987, Prinsenberg \& Bennett 1987 ) which measured current speed, direction, conductivity, temperature and pressure at 14 discrete depths $(0$ to $50 \mathrm{~m}$ ). Hourly profiles were made with GUMPS for only a few days in 1985, but CTD (conductivity and temperature versus depth as determined by pressure) profiles were obtained almost daily during the higher resolution biological sampling

\section{RESULTS}

\section{Water column structure, tidal cycles and nutrient fluxes}

In Fig. 1 we present representative profiles for concurrent observations of salinity, density and 2 dissolved inorganic nutrients. Water column structure was characterized by a shallow 'mixed layer' of 10 to $15 \mathrm{~m}$ depth, a pronounced pycnocline from about 15 to $40 \mathrm{~m}$ and a deeper isohaline layer around 50 to $60 \mathrm{~m}$ thick. Even though the so-called 'surface mixed layer' was isohaline (Fig. 1a) with very weak, if any, density stratification, there were strong and persistent gradients for both nitrate $\left(\mathrm{NO}_{3}\right)$ and silicic acid $\left(\mathrm{Si}(\mathrm{OH})_{4}\right)$ across this layer (Fig. 1b). Obviously, a strong sourcesink relationship is implied by the steep gradients across the 'mixed' upper layer. The main nutricline
Fig. 1. Concurrent vertical profiles of salinity and density (left) along with nitrate and silicic acid (right) in the water column beneath the sea ice taken on Day 139

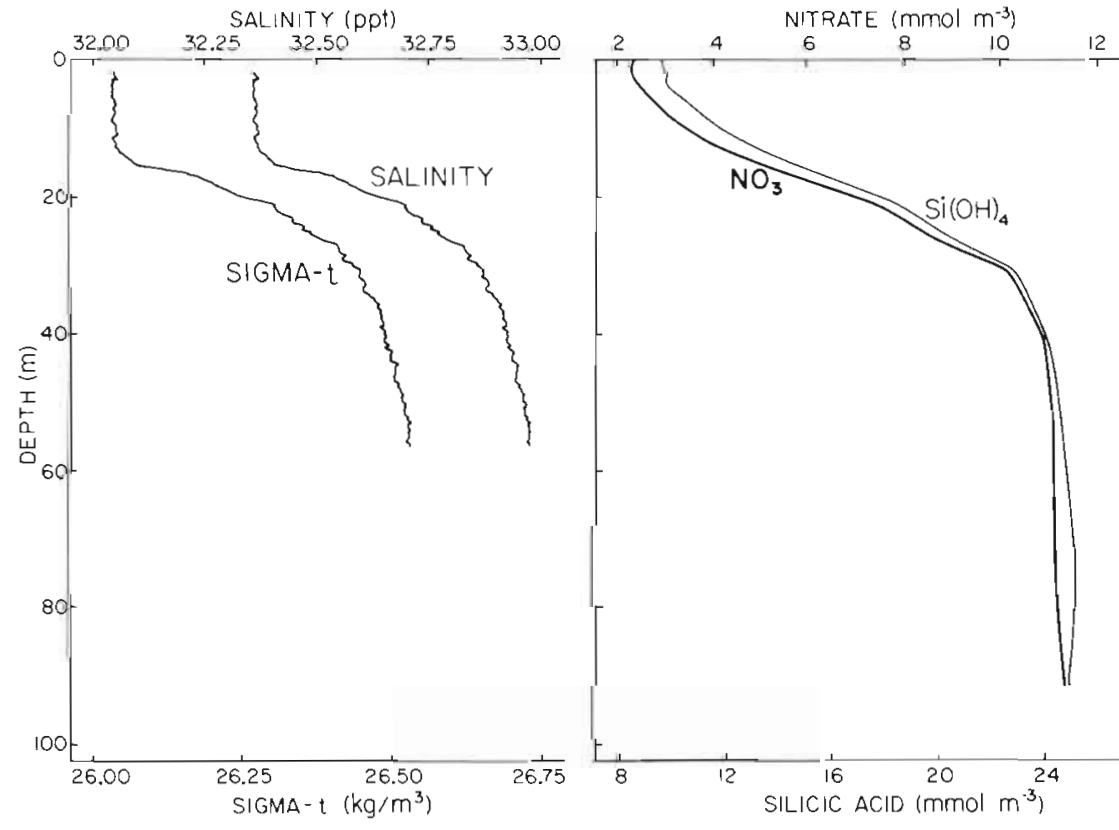


corresponded closely with the vertical position of the pycnocline-halocline; the lower portions of the nutrient profiles revealed little or no vertical structure.

Variations in maximum current speeds $\left(U, \mathrm{~cm} \mathrm{~s}^{-1}\right)$ are largely dependent upon tidal forcing with the fortnightly cycle evident in the current regime (Fig. 2a) and in eddy diffusivities (Fig. 2b; also see Fig. 8 of Cota et al. 1987). Hence, all observations have been related to tidal data which are generally available and reliable
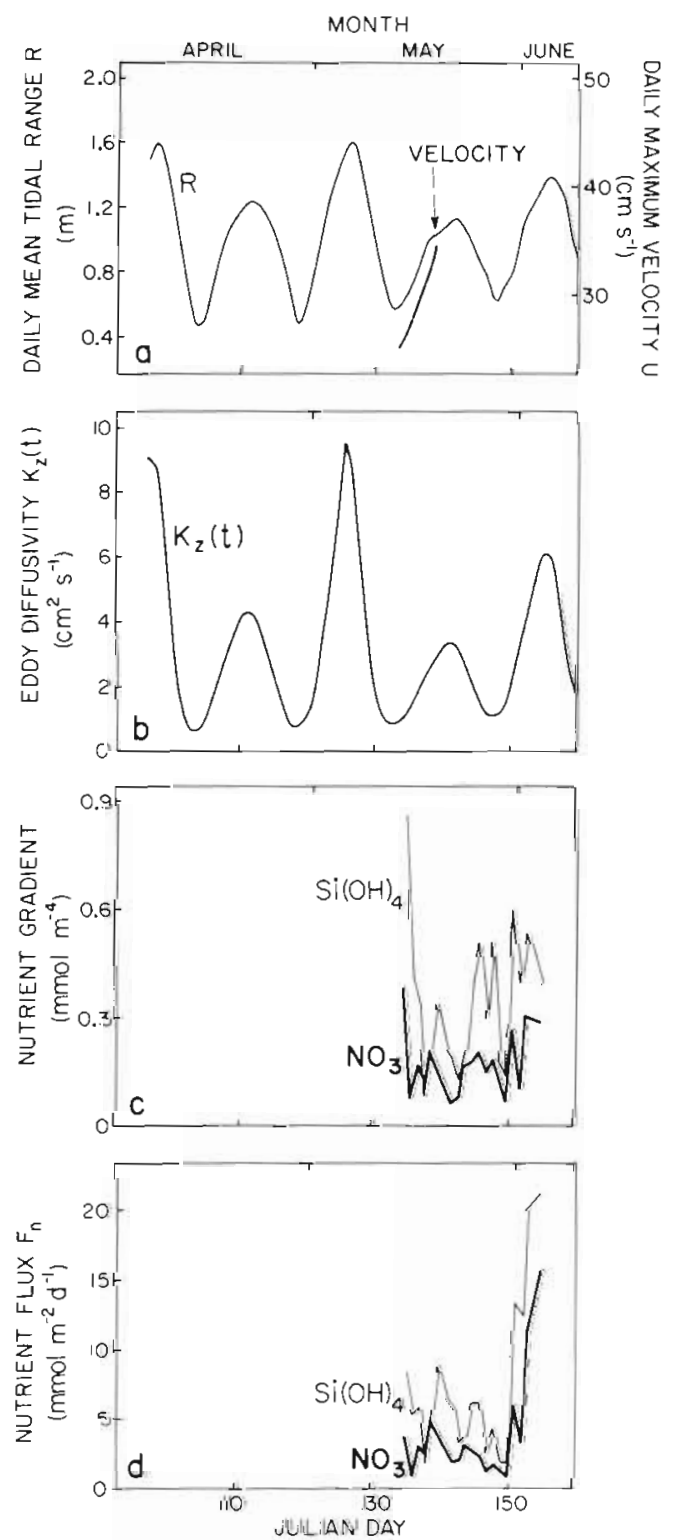

Fig. 2. Fluctuations of physical-chemical parameters in the surface 'mixed layer' versus tidal state during the spring ice algal bloom. (a) Predicted daily mean tidal range ( $R$, thin line) and observed maximum velocity ( $U$, short thick line) for $5 \mathrm{~d}$. (b) Predicted vertical eddy diffusivities $\left(K_{z}(t)\right)$. (c) Concentration gradients for nitrate $\left(\mathrm{NO}_{3}\right.$, thick line) and silicic acid $\left(\mathrm{Si}(\mathrm{OH})_{4}\right.$, thin line). (d) Estimated fluxes $\left(F_{n}\right)$ for both of these nutrients for this region. Nutrient gradients $(\Delta n / \Delta z)$ over the surface 'mixed layer' (Fig. 2c) were present even throughout the most intense periods of mixing which coincided with spring tides. Computations of vertical eddy diffusivities $K_{z}(t)$ as a function of time for the surface mixed layer were made with a polynomial expression reported by Cota et al. (1987; their Eq. 11) which relates daily mean tidal range ( $R$, in meters) to vertical diffusivity. Estimates of vertical nutrient fluxes $F_{n}$ were obtained from:

$$
F_{n}=(\Delta n / \Delta z) \cdot K_{z}
$$

employing the gradient transport hypothesis. Even though there were 8 or 9 observations in the upper layer, we again found no clear relationship between nutrient gradients within the surface 'mixed layer' and tidal range (Fig. 2C), but the magnitude of the nutrient gradients and the estimated fluxes (Fig. 2d) in this layer were considerably higher than our previous observations (Cota et al, 1987). Microscale nutrient profiles over the top meter $(1,3,7,15,25,50$ and $100 \mathrm{~cm})$ failed to resolve consistent gradients or patterns near the boundary (Cota unpubl.). There was, on the other hand, a strong relationship between tidal range and nutrient gradients in the pycnocline-nutricline similar to our previous results (see Fig. 9 of Cota et al. 1987). Gradients of nitrate and silicic acid in the pycnocline displayed a clear dependence upon tidal range over time, $R(t)$, with respective correlation coefficients of 0.75 and 0.77 for the tidal state $2 \mathrm{~d}$ earlier. The nutrient gradients in the pycnocline can be represented by regression relationships:

$$
\begin{gathered}
\Delta \mathrm{NO}_{3} /\left.\Delta z\right|_{(t)}=-0.59+1.07 R_{(t-2)} \\
\Delta \mathrm{Si}(\mathrm{OH})_{4} /\left.\Delta z\right|_{(t)}=-0.52+1.24 R_{(t-2)}
\end{gathered}
$$

where the gradients have units of mmol $\mathrm{m}^{-4}$, tidal range $R$ is in meters and time $t$ is in days with a $2 \mathrm{~d}$ lag. The standard deviations were 0.16 for nitrate and 0.21 for silicic acid in Eqs. (4) and (5), respectively. The nutrient gradients across the pycnocline also sharpen as the thickness of the pycnocline decreases with the increased shear during the stronger spring tidal currents.

\section{Ice algal dynamics and physiological periormance}

The temporal response of the ice algal community is summarized by the time series of observations (Fig. 3) under low snow where algal biomass was normally highest. Chlorophyll biomass (CHL, Fig. 3a) increased throughout April (establishment phase) and then exhibited low frequency fluctuations until the relatively rapid decline of the bloom in late May-early June. However, these data lack sufficient temporal 

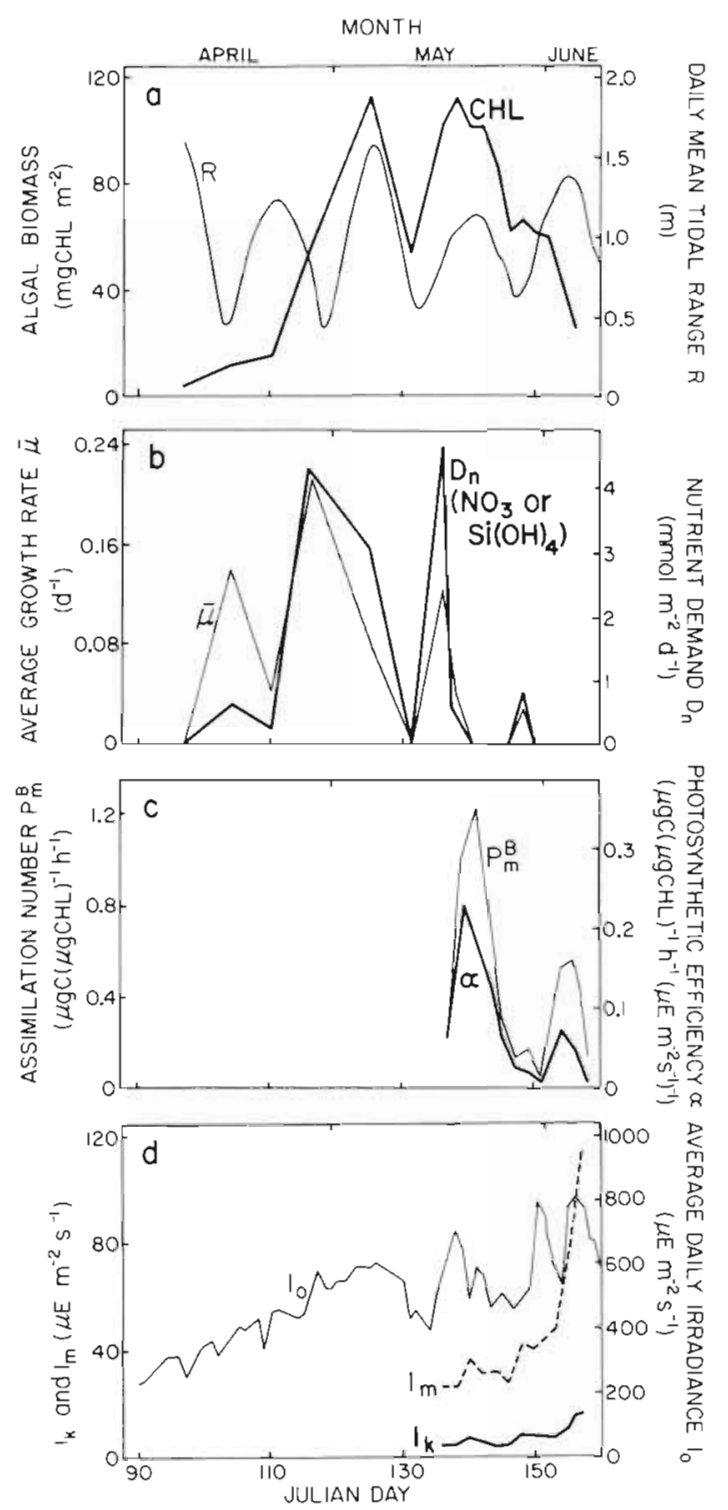

Fig. 3. Temporal changes in several indices describing ice algail performance for populations from low snow cover are shown in relation to tidal state and incoming irradiance. (a) Chlorophyll (CHL, thick line) and daily mean tidal range $(R$, thin line). The algae began rapidly sloughing off the ice around Day 147. (b) Average growth rate $(\mu)$ and estimated nutrient demand $\left(D_{n}\right)$. (c) Photosynthetic performance as indicated by maximum assimilation number $\left(P_{m}{ }^{B}\right.$, thin line) and photosynthetic efficiency ( $\alpha$, thick line) over the latter portion of the bloom. (d) Photoadaptive index, $I_{k}$ (thick line), optimal irradiance $\left(I_{m}\right.$, dashed line) for photosynthesis and average daily incident irradiance $\left(I_{o}\right.$, thin line). Confidence intervals for the primary photosynthetic parameters were similar to those in Table 1

resolution to ascribe frequency and phase relations adequately. Average specific growth rates $\left(\mu, \mathrm{d}^{-1}\right)$ based on changes in chlorophyll crops tended to be highest during the earlier part of the bloom (Fig. 3b) when biomass levels were lowest and there should have been less demand for the available nutrients. Nutrient demand $\left(D_{\mathrm{n}}\right.$, Fig. $\left.3 \mathrm{~b}\right)$ was computed with the relationship:

$$
D_{n}=\mu \quad B_{n}
$$

where $B_{n}$ is the nutrient element's biomass estimated by assuming constant ratios of mass (W/W) for cellular constituents (i.e. 35:1 for C:chl, 7:1 for C:N, 5:1 for N:chl and $10: 1$ for $\mathrm{Si}: \mathrm{chl}$ ) which are similar to observed average values (Cota et al. 1987). Given their 2-fold difference in mass, demand for nitrogen (atomic wt $=14$ ) as nitrate and silicon (atomic wt $=28$ ) as silicic acid are identical with these ratios when expressed as $\mathrm{mmol} \mathrm{m} \mathrm{m}^{-2} \mathrm{~d}^{-1}$. Estimates of growth rate and nutrient demand are plotted as interval end points (Fig. 3b) but they represent interval averages for the preceeding 2 to $7 \mathrm{~d}$ periods.

Several photosynthetic parameters characterize the photoadaptive state(s) of the low snow population over the course of our time series observations. Two key indices of the algal photosynthethic performance displayed significant oscillations over time. Both maximum assimilation rate $\left(P_{m}^{B},\left(\mathrm{mgC}(\mathrm{mgchl})^{-1} \mathrm{~h}^{-1}\right)\right.$; Fig. $3 c)$ and photosynthetic efficiency $\left(\alpha,\left[\mathrm{mgC}(\mathrm{mgchl})^{-1}\right.\right.$ $\left.\mathrm{h}^{-1}\left(\mu \mathrm{E} \mathrm{m}^{-2} \mathrm{~s}^{-1}\right)^{-1}\right)$ the light-limited initial slope of the P-I curve; Fig. 3c) varied by as much as an order of magnitude in $3 \mathrm{wk}$; these parameters varied in concert with the fortnightly tides. Values of $\beta$, the slope of the P-I curve at high intensity (same units as $\alpha$ ), did not change systematically and were zero or very small for low snow populations, indicating there was little photoinhibition in these cells. The precision of estimates of $P_{m}{ }^{B}, \alpha$ and $\beta$ are about $\pm 5 \%, \pm 10 \%$ and $\pm 50 \%$, respectively (Gallegos \& Platt 1981, Harrison \& Platt 1986). Two other descriptive parameters were relatively constant up until the last few days of the time series. These parameters included $I_{k}$, which is an index of photoadaptation (Talling 1957, Platt et al. 1980) defined as $P_{m}^{B} / \alpha_{1}$ and $I_{m}$, the optimal irradiance for photosynthesis (Fig. 3d). All values of $I_{k}$ and $I_{m}$ ranged from about 4 to $8 \mu \mathrm{E} \mathrm{m}^{-2} \mathrm{~s}^{-1}$ and 25 to $50 \mu \mathrm{E} \mathrm{m}^{-2} \mathrm{~s}^{-1}$, respectively, from mid-April (Day 118) to early June (Day 153), and then in just $4 \mathrm{~d}$ they increased to values exceeding 16 and $110 \mu \mathrm{E} \mathrm{m}^{-2} \mathrm{~s}^{-1}$.

Ice algal populations from 4 different snow depths or light environments were collected at a nearby site about $100 \mathrm{~m}$ away. These cells also revealed large and consistent differences in their photosynthetic parameters when measured at the extremes in tidal state (Table 1). During either tidal extreme, photosynthetic efficiencies were similar over the entire range of snow covers, but the values varied significantly over time. Ice algae from all snow depths (light histories) also displayed much lower assimilation rates during the neap tide, when nutrient fluxes are lowest and the algae are assumed to be most nutrient-stressed. The populations 
Table 1 Photosynthetic parameters for ice algal populations from 4 snow depths measured on Days 141 and 148 which corresponded to spring and neap tidal states, respectively, $\alpha$ : initial light-limited slope of the $P$ - $I$ curve; $\beta$ : slope at high light intensities; $P_{m}^{B}$ maximum assimilation rate; $I_{k}$ : an index of photoadatation $\left(I_{k}=P_{m}^{B} / \alpha\right)$. Units are given below and values in parentheses are $90 \%$ confidence limits of the primary parameter estimates

\begin{tabular}{|c|c|c|c|c|c|c|c|c|}
\hline \multirow[b]{2}{*}{ Snow cover } & \multicolumn{4}{|c|}{ Spring tide } & \multicolumn{4}{|c|}{ Neap tide } \\
\hline & $\alpha$ & $\begin{array}{c}\beta \\
\left(10^{-3}\right)\end{array}$ & $P_{m}^{B}$ & $I_{k}$ & $\alpha$ & $\begin{array}{c}\beta \\
\left(10^{-3}\right)\end{array}$ & $P_{n}^{B}$ & $I_{k}$ \\
\hline $\begin{array}{l}\text { Clear } \\
(0 \mathrm{~cm})\end{array}$ & $\begin{array}{c}0.27 \\
(0.02)\end{array}$ & $\begin{array}{c}0.0 \\
(0.8)\end{array}$ & $\begin{array}{c}4.9 \\
(0.2)\end{array}$ & 18.1 & $\begin{array}{c}0.036 \\
(0.004)\end{array}$ & $\begin{array}{c}0.0 \\
(0.1)\end{array}$ & $\begin{array}{c}0.78 \\
(0.03)\end{array}$ & 21.9 \\
\hline $\begin{array}{l}\text { Low } \\
(3-5 \mathrm{~cm})\end{array}$ & $\begin{array}{c}0.41 \\
(0.05)\end{array}$ & $\begin{array}{c}0.0 \\
(1.0)\end{array}$ & $\begin{array}{c}1.9 \\
(0.1)\end{array}$ & 4.7 & $\begin{array}{c}0.036 \\
(0.004)\end{array}$ & $\begin{array}{c}0.1 \\
(0.03)\end{array}$ & $\begin{array}{c}0.20 \\
(0.01)\end{array}$ & 5.5 \\
\hline $\begin{array}{l}\text { Moderate } \\
(10-13 \mathrm{~cm})\end{array}$ & $\begin{array}{c}0.27 \\
(0.03)\end{array}$ & $\begin{array}{c}1.0 \\
(0.5)\end{array}$ & $\begin{array}{c}1.1 \\
(0.03\}\end{array}$ & 4.0 & $\begin{array}{c}0.038 \\
(0.005)\end{array}$ & $\begin{array}{c}0.3 \\
(0.1)\end{array}$ & $\begin{array}{c}0.19 \\
(0.01)\end{array}$ & 4.9 \\
\hline $\begin{array}{l}\text { Heavy } \\
(20-25 \mathrm{~cm})\end{array}$ & $\begin{array}{c}0.36 \\
(0.05)\end{array}$ & $\begin{array}{c}1.4 \\
(0.4)\end{array}$ & $\begin{array}{l}1.1 \\
(0.1)\end{array}$ & 3.0 & $\begin{array}{c}0.034 \\
(0.004)\end{array}$ & $\begin{array}{l}0.4 \\
(0.03)\end{array}$ & $\begin{array}{c}0.22 \\
(0.01)\end{array}$ & 6.2 \\
\hline
\end{tabular}

from the snow-free area consistently exhibited the highest assimilation numbers.

The values of $\beta$ in Table 1 also suggest that there was little evidence of photoinhibition in populations adapted to the higher light levels under little or no snow. The highest intensities in our experiments were about 150 to $200 \mu \mathrm{E} \mathrm{m}^{-2} \mathrm{~s}^{-1}$ which is about 3 to 10 times higher than maximum irradiance in situ depending upon snow cover (Cota 1985, Smith et al. 1988). On the other hand, algae from relatively low light environments under deeper snow covers were obviously photoinhibited at irradiances above ca $40 \mu \mathrm{E} \mathrm{m}^{-2} \mathrm{~s}^{-1}$ (ca 3 to $4 \%$ of incident irradiance at solar noon) and these cells appeared to be even more sensitive during spring tides (Table 1). Values of $I_{k}$, in Table 1 were only roughly related to the light gradient for snow cover, but they clearly indicate that the algae were adapted to very low light and that they are often light-saturated at in situ irradiances (Cota 1985, Smith et al. 1988).

\section{DISCUSSION}

During spring, ice algae in the high Arctic exist largely at the ice-water interface in a dense but nearly planar environment which, despite its small scale, is probably stratified in the vertical because the 2 most important resources, which are potentially limiting. have sources above and below the populations. Most light is reflected at the snow surface because of the high albedos (Maykut 1985) and light which finally reaches these cells within the ice algal layer must pass through overlying snow, ice and algae (SooHoo et al. 1987. Smith et al. 1988). Nutrients sufficient to sustain the observed biomasses must be supplied primarily from the water column (Cota et al. 1987). The fluxes of these important environmental variables appear to dominate the temporal development of biomass and the physiological response(s) of the ice algae in this arctic ecosystem. Resource availability also changes over the course of the spring bloom because both resources are subject to density-dependent effects. The ice algae must optimize their growth rates to the ambient light and nutrient regimes which have different but overlapping scales of temporal variability. Incident light varies primarily seasonally and over diel scales. Nutrient fluxes are closely related to the tides which dominate the physical forcing for this system.

Even in a relatively predictable ecosystem it is difficult to segregate the influences of limiting environmental variables completely because there are often interactive effects which cannot be simulated by simpler systems. Both light and nutrient limitation probably play important roles in epontic ecosystems and may be influential simultaneously. We have tried to identify the dominant effects of these 2 environmental variables because we believe they are the most important physical-chemical determinents in the system and they seem to have characteristic signals in the photosynthetic behavior of the ice algae. A relatively quiescent period in late spring (May) was chosen for these observations because changes in most environmental variables are comparatively small throughout most of this period and populations which have gone through at least several generations should be adapted to their conditions.

\section{Ice algal response to light}

The cells from the highest light environment in the snow-free region exhibited the highest rates of production at both tidal extremes (Table 1), indicating that 
these algae are indeed capable of photoadaptation to relatively high irradiances and that they are not an obligate shade flora (Smith et al. 1987, 1988) as suggested previously because of the relatively low biomass and poor photosynthetic performance of cells from snow-free regions (Cota 1985). However, pigment biomass was again lowest in the cleared area $(0 \mathrm{~cm}$ snow) throughout most of the bloom; this trend toward low biomass under areas with no snow is typical even though there can be as much as a 2-fold difference in carbon to chorophyll ratios between the extremes in snow cover (Cota et al. 1987). High levels of ice algal biomass presumably cannot be maintained under cleared regions, because the algae are such efficient black bodies that they melt themselves off their substrate. Similar observations have been made under cleared (snow-free) areas in the Arctic (Appolonio 1961, 1965) and the Antarctic (Grossi et al. 1987) where biomass levels declined well before adjacent snowcovered regions. Lewis \& Cota (unpubl.) have considered the potential for habitat alteration by ice algal populations and estimated that absorption of radiation by ice algae may account for up to $25 \%$ of the heat flux in late spring in the Arctic when biomass levels are relatively high and the snow cover and ice sheet are comparatively thin.

To a large degree temperature, salinity and mean daily light can be considered as constants during most of May, the latter half of the bloom. Surface water temperature varies only from about -1.70 to $-1.80^{\circ} \mathrm{C}$ and salinity is around 32 to 32.5 (Cota et al. 1987. Prinsenberg \& Bennett 1987). Continuous daylight is the norm after 27 April at this latitude, although there is still a pronounced diel cycle in the absolute solar flux because of sun angle. Average daily values of photosynthetically active radiation (PAR) incident at the snow-ice surface $\left(I_{0}\right.$; Fig. $\left.3 \mathrm{~d}\right)$ more than doubled in April and then varied by $30 \%$ or less of the mean monthly value during May. PAR was estimated as one half of total incoming irradiance (Platt et al. 1980) and was based on records from Atmosphere and Environment Canada for their Resolute station which was within $10 \mathrm{~km}$ of our study area. Furthermore, this is a consistent seasonal pattern in their historical data of 30 yr normals. Measurements of transmitted light below the ice have been summarized by Smith et al. (1988).

The onset of snow melting and 'flushing' of the ice sheet (Maykut 1985) produced a visible lens or layer of relatively fresh water near the end of our observational period. In response to the rapid changes in their physical environment the algae started sloughing off the ice in sheets near the end of May (about Day 147. Fig. 3a) and the last $2 P-I$ experiments were made on sloughed populations. Low salinities are known to affect growth (Grant \& Horner 1976, Vargo et al. 1986) as well as fluorescence and photosynthesis (Bates \& Cota 1986) of ice algae. The failure of the algae to attain higher levels of biomass (Fig. 3a) and their somewhat lower photosynthetic performance (Fig. 3c) must have been influenced by these events. Also, as might be expected, during this period when light penetration increases rapidly with decreasing snow cover, values of $I_{k}$ and the optimal irradiance for photosynthesis, $I_{m}$, increased markedly (Fig. 3d). In the last few days of our study these parameters more than doubled their magnitudes in response to the rapidly changing light regime. Introductions of fresh water from melting snow and sea ice tend to dilute the available nutrients (Cota et al. unpubl.) and also enhance density stratification, thus impeding both vertical mixing and nutrient fluxes in ice-covered marine (Cota et al. 1987) and estuarine environments (Gosselin et al. 1985).

\section{Ice algal response to nutrients}

With good vertical resolution ( 9 points in the top $15 \mathrm{~m}$ ) steep and persistent nutrient gradients across the 'surface mixed layer' have been documented (Figs. $1 \mathrm{~b}$ and 2c), clearly indicating that ice algae constitute a strong sink for nutrients. Current speeds up to $50 \mathrm{~cm} \mathrm{~s}^{-1}$ were not sufficiently strong to eradicate these gradients; furthermore, nutrient gradients were usually steeper in surface waters in 1985 (this study) when algae were more abundant compared with 1983 and 1984 (Cota et al. 1987 and unpubl.). The nutrient gradients across the pycnocline display a clear correspondence with tidal range as evidenced by the relationships described in Eqs. (4) and (5) (see also Fig. 9 of Cota et al. 1987). Nutrients from the mixed layer which are consumed by ice algae must be resupplied primarily from below

Fluxes of inorganic nutrients are largely determined by nutrient gradient (Fig. 1b) and by tidally induced mixing (Fig. 2b) which in this ice-covered marine system show a strong fortnightly signal in the surface 'mixed layer' and the pycnocline (Cota et al. 1987). Fluctuations in nutrient supply appear to influence the maximum biomass (Fig. 3a; Cota et al. 1987), photosynthetic parameters (Fig. 3C) and patterns of photosynthate allocation of ice algal populations in the high Arctic (Smith et al. 1987). This temporal variation of biomass and photosynthetic behavior is presumed to reflect the variable nutrient status of the algae (Gosselin et al. 1985, Cota et al. 1987, Smith et al. 1987). Although we can only speculate about the mechanisms responsible for changes in biomass, it appears that, when stressed, cells are more prone to export (e.g. sinking or erosion) and biomass levels may decline periodically. Biomass levels may also attain maxima determined by light (Smith et al. 1988) and/or nutrient supply (this study) and then effec- 
tively melt themselves off the ice (Lewis \& Cota unpubl.). At lower biomass levels typical of other light environments (snow depths), biomass fluctuations, if any, were less pronounced; this feature may be explained, in part, by lower growth rates and smaller absolute nutrient requirements at sites with less biomass where 'average' nutrient fluxes would be less likely to be limiting (Cota et al. 1987).

The potential contributions of alternate mechanisms of nutrient supply, including the regeneration of silicic acid and/or desalination of the ice sheet, are predicted to be small (Cota et al. 1987 and unpubl.), compared to total nutrient demand integrated over the entire spring bloom (Fig. 3b), whereas nutrient fluxes in the water column are usually of the same order of magnitude as demand (Fig 2d). However, it should be stressed that our estimates of nutrient demand are conservative; demand was based on changes in net standing stocks (approximates net community production) and no corrections were made for expected losses of biomass (e.g. respiration, grazing, erosion or sinking, etc.). If we assume that exports of algal biomass are high and that gross annual production for a $50 \mathrm{~d}$ bloom period is on the order of 5 to $25 \mathrm{~g} \mathrm{C} \mathrm{m}^{-2} \mathrm{yr}^{-1}$ (Smith et al. 1988), then nutrient demand averages 1 to $5 \mathrm{mmol} \mathrm{N}$ or Si m $\mathrm{m}^{-2} \mathrm{~d}^{-1}$ over the entire bloom and these levels of demand would often exceed nutrient fluxes in the surface mixed layer (Fig. 2d). Assuming a $24 \mathrm{~h}$ photoperiod, maximal rates of production $\left(P_{m}^{B}\right)$ in situ, and a constant $C: c h l$ ratio of 35 , growth rates calculated from ${ }^{14} \mathrm{C}$ fixation rates indicate that ice algae were growing at about 0.23 $\pm 0.15 \mathrm{~d}^{-1}$, which is almost half of their tempraturelimited maximum rate, over the last 3 wk of our study. Values of ${ }^{14} \mathrm{C}$-growth rate ranged from $0.03 \mathrm{~d}^{-1}$ at neap tide to $0.49 \mathrm{~d}^{-1}$ during the earlier spring tide (Fig. 3c); rates for the second spring tide were only slightly above the period average. These physiologically based estimates imply that growth rates were, on average, suboptimal and that exports must have been considerable because standing crops were declining over most of this period. Direct measurements of sedimentation suggest relatively low rates of export (Carey 1987 , Anning pers. comm.)

The evidence regarding the existence of a relationship between assimilation number and nutrient stress in phytoplankton is equivocal. Some investigators have suggested that relatively low assimilation rates are characteristic of populations from oligotrophic oceanic waters (Thomas 1970, Vedernikov 1975), however in a eutrophic coastal system assimilation numbers were not necessarily well correlated with nutrient concentration because of regenerative fluxes (Harrison \& Platt 1980). Results from laboratory cultures of phytoplankton are less ambiguous with most evidence displaying decreasing assimilation numbers with increasing nutrient limitation (Thomas \& Dodson 1972, Laws \& Bannister 1980, Osborne \& Geider 1986), although Eppley \& Renger's (1974) results indicate that assimilation number is invariant with nutrient stress. Nevertheless, 2 independent but concurrent time series of assimilation numbers for the ice algae from our study area have revealed trends largely consistent with respect to the predicted tidally-variant nutrient supply (Smith et al. 1987). Observations on phytoplankton also suggest that interpretations of field data should consider environmental variables as well as changes of species and cellular composition (Glover 1980, Eppley 1981, Falkowski 1981). Changes in species or chemical composition were minor, but may, in part, contribute to the observed physiological oscillations evident in Fig. 3 (Smith et al. 1987 and unpubl.).

The literature on the impact of nutrient stress on $\alpha$, the initial slope of the photosynthesis-irradiance response, is not extensive for microalgae. Welschmeyer \& Lorenzen (1981) found $\alpha$, quantum efficiency $(\phi)$ and in vivo fluorescence to be sensitive to nutrient status in batch cultures with progressive nutrient starvation. In contrast, Osborne \& Geider's (1986) results showed $\alpha$ was nearly constant in continous cultures over a range of nutrient supply rates. Photochemical capacity, as indicated by reductions in fluorescence yield, may also be diminished with nutrient-stressed cells (Kiefer 1973, Welschmeyer \& Lorenzen 1981, Rosen \& Lowe 1984). Estimates of $\alpha$ in field studies of natural phytoplankton populations revealed variation with depth and season (Platt \& Jassby 1976). Harrison \& Platt (1986) examined a very large data set on the photosynthetic performance of phytoplankton in relation to ancillary oceanographic data and suggested that $P-I$ parameters are largely under physical control but concluded that light and temperature appear to be the most important environmental variables for phytoplankton.

Our data clearly show that values of $\alpha$ for these ice algae attain unusually high levels and vary significantly with time, on scales consistent with tidal forcing (Fig. 3c). In a subarctic estuary (Manitounuk Sound, Hudson Bay) Gosselin et al. (1985) found similar trends in photosynthetic efficiences but not assimilation rate for ice algae. They speculated that phosphorus was the limiting nutrient in this estuarine environment. Their peak values of efficiencies were about 0.20 (mgC $[\mathrm{mg} \mathrm{chl}]^{-1} \mathrm{~h}^{-1}\left[\mu \mathrm{E} \mathrm{m} \mathrm{m}^{-2} \mathrm{~s}^{-1}\right]^{-1}$ ) with 5 values of 0.10 or more. Subsequently, they reported average early and late season values of $0.11 \pm 0.07(n=10)$ and $0.32 \pm$ $0.13(n=3)$, respectively, for a more typical marine location offshore in Hudson Bay (Gosselin et al. 1986). In natural populations of phytoplankton from both temperature and polar environments $(n>700)$ values of $\alpha$ ranged up to about $0.06(\mathrm{mgC}[\mathrm{mgch}\}]^{-1} \mathrm{~h}^{-1}[\mu \mathrm{E}$ $\left.\mathrm{m}^{-2} \mathrm{~s}^{-1} \mathrm{~J}^{-1}\right)$; only about 50 observations were above 
0.03 but higher values of $\alpha$ were more frequent at high latitude (Harrison \& Platt 1986). These high values of $\alpha$ for ice algae are exceptional because they suggest that mean specific absorption coefficients for these algal populations must, on occasion, be unusually high compared to most microalgae (e.g. SooHoo et al. 1987). In model calculations based upon light transmission through snow, sea ice and ice algae, we derived a mean spectral extinction coefficient for chlorophyll in situ of $0.035 \mathrm{~m}^{2} \mathrm{mg} \mathrm{chl}^{-1}$ for the 1985 data set (Smith et al. 1988). Large complements of accessory pigments may help to explain high photosynthetic efficiencies. Incomplete extraction of chlorophyll or systematic underestimation of irradiance would also aggravate this problem, but, at least in our case, there was nothing unusual or exceptional with these particular experiments. Quantum yields ( $\phi$ ) can be estimated from:

$$
\phi=\alpha /\left(43.20^{\circ} \bar{a}\right)
$$

where ${ }^{\circ} \bar{a}=$ spectrally averaged absorption coefficient (SooHoo et al. (1987). When typical absorption coefficients for microalgae are employed $\left(\approx 0.01 \mathrm{~m}^{2} \mathrm{mg}\right.$ $\mathrm{chl}^{-1}$ ) in these calculations, the results are well above the commonly accepted theoretical maximum of 0.1 mol C (Ein. absorbed) ${ }^{-1}$ (SooHoo et al. 1987). Nevertheless, it is difficult to dismiss these observations as mere anomalies when concurrent observations ( $n=$ 7 for values $\geq 0.13$ ) have been made simultaneously under 4 different snow depths and 3 times over a $5 \mathrm{~d}$ period under low snow at sites about $100 \mathrm{~m}$ apart at our study site in the Northwest Passage as well as in the Subarctic by independent investigators $(n \approx 10$ for values $\geq 0.10$; Gosselin et al. 1985, 1986). Further work is needed to help elucidate the photosynthetic performance of natural populations of microalgae in response to environmental variability. If variations of physiological performance of this magnitude and frequency are typical for these ice algae, then estimates of seasonal productivity with low temporal resolution could lead to serious over- or underestimates. Variability on this and, perhaps, shorter time scales should be considered in ecosystem production estimates.

Nutrient conditions sufficient for balanced algal growth at optimal rates are not easily defined in a variable environment, because nutrient fluxes are subject to physical and biological forcing. Nutrient concentrations measured over much larger scales may also be misleading. If demand is comparable to supply, then fluxes may be high even when concentrations are relatively low and vice versa. During this study nutrient concentrations in the water and skeletal ice were never very low (Cota et al. unpubl.), but the fluxes in the water column were predicted to vary by an order of magnitude or more. The ice sheet is not growing during the latter half of the algal bloom, and convective flushing of the brine tubes in the skeletal layer, which results from brine rejection at an accreting interface, should be absent or greatly diminished (Reeburgh 1984). Furthermore, the nutrient uptake chacteristics of these ice algae are not known; they may have low affinities (i.e. relatively large halfsaturation constants) for nutrient uptake (Azam 1974, Jacques 1983, Maestrini et al. 1986).

More importantly, the actual nutrient concentrations and fluxes in the microenvironment of the algae have not been measured directly. Suitable new technologies must be employed to examine fluxes on scales of $\mu \mathrm{m}$ to $\mathrm{mm}$ to resolve this question. The algae colonize the interstices of the skeletal layer (scales of $<1 \mathrm{~mm}$ to ca 2 $\mathrm{cm}$ ) of the ice sheet, and their nutrient supply is ultimately limited by molecular diffusion across the viscous sublayer, the linear region of the velocity profile near the boundary. Recent measurements at our study site reveal that the non-dimensional thickness of the sublayer is thicker than expected and may often exceed $5 \mathrm{~mm}$ (Chriss \& Horne unpubl.). Rates of nutrient supply directly to the algae will be largely a function of the diffusion gradient across the sublayer and the thickness of the sublayer. Algal consumption will steepen the gradient and regeneration in the bottom ice will tend to weaken it. Vertical mixing in the surface mixed layer will also steepen the gradient by maintaining higher concentrations below the sublayer. Hence, if demand keeps pace with supply, then the gradient across the viscous sublayer will remain steep.

Several types of observations support our inference that arctic ice algae may be influenced, directly or indirectly, by nutrient flux(es) from the water column, in particular silicic acid. The cogent evidence includes changes in the relative abundance of nutrients in sea ice (Grainger 1977, Cota et al. unpubl.), comparisons of minimal nutrient demand versus rates of supply (Cota et al. 1987), steep and persistent gradients in surface 'mixed layers' (this study) and low frequency fluctuations in photosynthetic performance (Gosselin et al. 1985, Smith et al. 1987, this study). Ice algae have a large impact on nutrient distributions in seawater and sea ice; large pools of soluble phosphorus and nitrogen (nitrate and ammonium) occur in the ice algal layer, but silicon is rarely in excess, at least in a dissolved reactive form (Cota et al. unpubl.).

To date virtually all of the reported accounts on ice algal biomass and physiology from the Arctic, including this work, have presented data which represent ensemble averages for algal assemblages from the lower 3 to 20 $\mathrm{cm}$ of the ice sheet. These values correspond, implicitly or explicitly, to populations integrated horizontally over the surface area of the ice sample and vertically over the length of the ice sample. In spring ice algae in the high Arctic are overwhelmingly concentrated in the bottom 
few centimeters of the ice sheet which is relatively warm and has direct contact with surface seawater. Recent observations have shown that even in the bottom centimeter of the algal band there is significant vertical zonation in nutrients, light and biomass (Conover et al. 1988, Smith et al. 1988, Cota et al. unpubl., R. E. H. Smith pers. comm.). These results suggest that algae from the top of the thin but dense algal layer may be limited by nutrients, probably silicon (Cota et al. 1987) while those at the bottom of this layer may experience light limitation (Smith et al. 1988). Dense populations of ice algae almost certainly experience some degree of light limitation from self-shading toward the bottom of the algal layer, even though most observations from the Arctic indicate that ice algal populations are normally well below their lightlimited maximum biomass (Smith et al. 1988). Measurements with better vertical resolution over millimeter scales in bottom ice will probably reveal that the thin ice algal layer has many parallels with euphotic zone mixed layer models of planktonic systems.

\section{CONCLUSIONS}

These results confirm that ice algae in the high Arctic are indeed highly shade-adapted with low photoadaptive indices $\left(I_{k}\right)$ and high photosynthetic efficiencies $(\alpha)$. However, the photosynthetic performance of populations from any given light environment, which is determined by the depth of snow cover, appears to be controlled primarily by their nutrient supply, at least during the latter half of the spring bloom when biomass levels are relatively high. Our results indicate that maximum ice algal biomass, assimilation numbers, photosynthetic efficiencies and perhaps sensitivity to photoinhibition are influenced by the pulsed nutrient supply. Independent observations from a time series under low snow cover (Fig. 3c) and several snow depths (Table 1) both show that maximum assimilation rates and the photosynthetic efficiencies of the ice algae vary significantly at frequencies similar to the fortnightly tides (Fig. 3a). Photosynthetic efficiencies were nearly the same for all cells over the natural range of snow covers but assimilation rates were considerably higher in populations from a snow-free area (Table 1). Estimates of annual ice algal production should consider the low frequency variability in rates of production.

Acknowledgements. This work was supported by the National Sciences and Engineering Research Council of Canada, the Office for Energy Research and Development and the Polar Continental Shelf Project (Department of Energy, Mines and Resources). We thank P. Clement, M. Bergmann, C. Caverhill, $D$. Rudderham, $J$ Anning. $T$ Siferd and $B$. Fraser for assistance and Drs R. E. H. Smith, W G. Harrison, T Platt, S. J. Prinsenberg and $\mathrm{B}$. Welch for comments.

\section{LITERATURE CITED}

Apollonio, S. (1961). The chlorophyll content of arctic sea ice. Arctic 14: 197-200

Apollonio, S. (1965). Chlorophyll in arctic sea ice. Arctic 18: $118-122$

Azam, F. (1974). Silicic acid uptake in diatoms studies with [68Ge] germanic acid as a tracer Planta 121. 205-212

Bates, S. S., Cota, G. F. (1986). Fluorescence induction and photosynthetic responses of arctic icealgae to sample treatment and salinity. J. Phycol. 22: 421-499

Bradstreet, M. S. W., Cross, W. E. (1982). Trophic relationships at high arctic ice edges. Arctic 35: 1-12

Carey, A. G. Jr. (1985). Marine ice fauna: Arctic. In: Horner, R. A. (ed.) Sea ice biota. CRC Press, Cincinnati, p. 173-190

Carey, A. G., Jr. (1987). Particle flux beneath fast ice in the shallow southwestern Beaufort Sea, Arctic Ocean. Mar Ecol. Prog. Ser. 40: 247-257

Clasby, R. C., Alexander, V., Homer, R. (1976). Primary productivity of sea-ice algae. In: Hood, D. W., Burrell, D. C. (eds.) Assessment of the arctic marine environment: selected topics. Inst. Mar. Sci., Univ. Alaska, Fairbanks, p. 289-304

Conover, R. J., Cota, G. F., Harrison, W G., Horne, E. P. W., Smith, R. E. H. (1989). Ice-water interactions and their effect on biological oceanography in the Arctic Archipelago. In: Harington, C. R. (ed.) Canada's missing dimension: science and history in the Canadian Arctic Islands. National Museum Nat. Sci., Ottawa (in press)

Conover, R. J., Hermann, A. W., Prinsenberg, S. J., Harris, L. R. (1986). Distribution of and feeding by the copepod Pseudocalanus under fast ice during arctic spring. Science 232: $1245-1247$

Cota, G. F. (1985). Photoadaptation of high arctic ice algae Nature, Lond. 315: 219-222

Cota, G. F., Prinsenberg, S. J., Bennett, E. B., Loder, J. W., Lewis, M. R., Anning, J. L., Watson, N. H., Harris, L. R. (1987). Nutrient fluxes during extended blooms of arctic ice algae. J. geophys. Res. 92: 1951-1962

Dugdale, R. C., Goering. J. J. (1967). Uptake of new and regenerated forms of nitrogen in primary productivity Limnol. Oceanogr. 12: 196-206

Eppley, R. W. (1981). Relations between nutrient assimilation and growth in phytoplankton with a brief review of estimates of growth rate in the ocean. Can. Bull. Fish. Aquat. Sci. 210: 251-263

Eppley, R. W. Peterson, B. J. (1979). Particulate organic matter flux and planktonic new production in the deep ocean. Nature, Lond. 282. 577-680

Eppley, R. W., Renger E. H. (1974). Nitrogen assimilation of an oceanic diatom in nitrogen-limited continuous culture. $J$. Phycol. 10: 15-23

Falkowski, P. G. (1981). Light-shade adaptation and assimilation numbers. J. Plankton. Res. 3: 203-216

Gallegos, C. L., Platt, T (1981). Photosynthesis measurements on natural populations of phytoplankton: Numerical anâlysis. Can. Bull. Fish. Aquat. Sci 210: 103-112

Glover, H. E. (1980). Assimilation numbers in cultures of marine phytoplankton. J. Plankton Res. 2: 69-79

Gosselin, M. L., Legendre, L., Demers, S., Ingram, R. G. (1985). Reponses of sea-ice midroalgae to climatic and fortnightly tidal energy inputs (Manitounuk Sound, Hudson Bay). Can. J. Fish. Aquat. Sci. 42: 999-1006

Gosselin, M. L., Legendre, L., Therriault, J.-C., Demers, S. Rochet, M. (1986). Physical control of the horizontal patchiness of sea ice microalgae. Mar Ecol. Prog. Ser 29 : $289-298$ 
Grainger, E. H. (1977). The annual nutrient cycle in sea-ice In: Dunbar, M. J. (ed.) Polar oceans. Arctic Inst North America, Calgary, p. 285-301

Grainger, E. H., Mohammed, A. A., Lovrity, J. E. (1985). The sea ice fauna of Frobisher Bay, Arctic Canada. Arctic 38: 23-30

Grann, H. H., Braarud, T (1935). A quantitative study of the phytoplankton in the Bay of Fundy and the Gulf of Maine including observations on hydrography, chemistry and turbidity. J. Biol. Bd Can. 1: 219-467

Grant, W. S., Horner, R. A., (1976). Growth responses to salinity variation in four Arctic ice diatoms. J. Phycol. 12: $180-185$

Grossi, S. M., Kottmeier, S. T., Moe, R. L., Taylor, G. T., Sullivan, C. W. (1987). Sea ice microbiol communities. VI. Growth and primary production in bottom ice under graded snow cover. Mar. Ecol. Prog. Ser 35: 153-162

Harrison, W. G., Platt, T., (1980). Variations in assimilation number of costal marine phytoplankton: effects of environmental co-variates. J. Plankton Res. 2: 249-260

Harrison, W G., Platt, T (1986). Photosynthesis-irradiance relationships in polar and temperate phytoplankton populations. Polar Biol. 5: 153-164

Holm-Hansen, O., Lorenzen, C. J., Holmes, R. W., Strickland J. D. H. (1965). Fluorometric determination of chlorophyll. J. Cons. int. Explor. Mer. 30: 3-15

Horner, R. A (1985). Ecology of sea ice microalgae. In: Horner, R A. (ed.) Sea ice biota. CRC Press, Cincinnati, p. 83-103

Horner, R. A., Schrader, G. C. (1982). Relative contributions of ice algae, phytoplankton and benthic microalgae to primary production in nearshore regions of the Beaufort Sea. Arctic 35: 485-503

Jacques, G. (1983). Some ecophysical aspects of the Antarctic phytoplankton. Polar Biol. 2: 27-33

Kiefer, D. A. (1973). Chlorophyll a fluorescence in marine centric diatoms: response of chloroplast to light and nutrient stress. Mar Biol. 23: 39-46

Laws, E. A., Bannister, T T (1980). Nutrient- and light-limited growth of Thalassiosira fluviatilis in continous culture, with implications for phytoplankton growth in the ocean. Limnol. Oceanogr. 25: 457-473

Lewis, M. R., Horne, E. P. W., Cullen, J. J., Oakey, N. S., Platt, T. (1984). Turbulent motions may control phytoplankton photosynthesis in the upper ocean. Nature, Lond. 311: $149-150$

Lewis, M. R., Smith, J. C. (1983). A small volume, short incubation time method for measurement of phyotosynthesis as a function of incident irradiance. Mar Ecol. Prog. Ser. 13: 99-102

Maestrini, S. Y., Rochet, M., Legendre, L., Demers, S. (1986). Nutrient limination of the bottom-ice microalgal biomass (southeastern Hudson Bay, Canadian Arctic). Limnol. Oceanogr 31: 969-982

Maykut, G. A. (1985). The ice environment. In: Horner, R. A. (ed.) Sea ice biota. CRC Press, Cincinnati, p. 22-82

McConville, M. J., Mitchell, C., Wetherbee, R. (1985). Patterns of carbon assimilation in a microalgal community from annual sea ice, East Antarctica. Polar Biol, 4: 135-141

This article was submitted to the editor
Osborne, B. A., Geider, R. J. (1986). Effect of nitrate-nitrogen limitation on photosynthesis of the diatom Phaeodactylum tricornutum Bohlin (Bacillariophyceae). Plant Cell Environ. 9: $617-625$

Palmisano, A. C., Sullivan, C. W (1985). Pathways of photosynthetic carbon assimilation in sea ice microalgae from McMurdo Sound, Antarctica. Limnol. Oceanogr 30: $674-678$

Platt, T., Gallegos, C. L., Harrison, W. G. (1980). Photoinhibition of photosynthesis in natural assemblages of marine phytoplankton, J. mar. Res. 38: 687-701

Platt, T., Jassby, A. D. (1976). The relationship between photosynthesis and light for natural assemblages of coastal marine phytoplankton. J. Phycol. 12: 421-430

Prinsenberg, S. J., Bennett, E. B. (1987). Mixing and transports in Barrow Strait, the central part of the Northwest Passage. Cont. Shelf Res. 7: 913-935

Reeburgh, W. S. (1984). Fluxes associated with brine motion in growing sea ice. Polar Biol. 3: 29-33

Rosen, B. H., Lowe, R. L. (1984). Physiological and ultrastructural responses of Cyclotella meneghiniana (Bacillariophyta) to light intensity and nutrient limitation. J. Phycol. 20: 173-183

Smith, R. E. H., Anning, J., Clement, P., Cota, G. (1988) Abundance and production of ice algae in Resolute Passage, Canadian Arctic. Mar. Ecol. Prog. Ser. 48: 251-263

Smith, R. E. H., Clement, P., Cota. G. F., Li, W. K. W (1987). Intracellular photosynthate allocation and the control of arctic marine ice algal production. J. Phycol. 23: 124-132

SooHoo, J. B., Palmisano, A. C., Kottmeier, S. T., Lizotte, M. P. SooHoo, S., L., Sullivan, C. W. (1987). Spectral light absorption and quantum yield of photosynthesis in sea ice microalgae and a bloom of Phaeocystis pouchetii from McMurdo Sound, Ancarctica. Mar Ecol. Prog. Ser 39: 175-189

Sverdrup, H. U. (1953). On conditions for the vernal blooming of phytoplankton. J. Cons. Explor. Mer, 18: 287-295

Talling, J. F. (1957). The phytoplankton population as a compound photosynthetic system. New Phytol. 56: 133-149

Thomas, W H (1970). On nitrogen deficiency in tropical Pacific oceanic phytoplankton: photosynthetic parameters in poor and rich water. Limnol. Oceanogr. 15: 380-385

Thomas, W H., Dodson, A. N. (1972). Effect of interactions between temperature and nitrate supply on the division rates of two marine phytoflagellates. Limnol Oceanogr 17 ; $515-523$

Vargo, G. A., Fanning, K., Heil, C., Bell, L. (1986). Growth rates and the salinity responses of an Antarctic ice microflora community. Polar Biol. 5: 241-247

Vedernikov, V. I. (1975). Dependence of the assimilation number and concentration of chlorophyll-a on water productivity in different temperature regions of the world ocean. Oceanol. 15: 482-485

Walsh, J. E., Johnson, C. M. (1979). An analysis of Arctic sea ice fluctuation, 1953-1977. J. phys. Oceanogr. 9: 580

Welschmeyer, N. A., Lorenzen, C. J. (1981). Chlorophyllspecific photosynthesis and quantum effciency at subsaturating light intensities. J. Phycol. 17: 283-293

Manuscript received: July 13,1988

Revised version accepted: November 29, 1988 